Perinatology

pISSN'2508-4887 • elSSN 2508-4895
Original article

Perinatology Vol. 30, No. 3, September, 2019

https://doi.org/10.14734/PN.2019.30.3.147

\title{
Clinical Study of 31 Polydactyly Cases Ad- mitted to Neonatal Intensive Care Unit
}

\author{
Yongwook Lee, MD', \\ Mihyeon Gang, MD', \\ Meayoung Chang, MD, PhD', \\ Wungjoo Song, $\mathrm{MS}^{2}$, \\ Sookza Kim, MD, PhD ${ }^{1,2}$ \\ 'Department of Pediatrics, \\ Chungnam National University \\ Hospital, Daejeon; ${ }^{2}$ Korea Genetics \\ Research Center, Cheongju, Korea
}

Received: 16 April 2019

Revised: 20 May 2019

Accepted: 28 May 2019

Correspondence to

Sookza Kim, MD, PhD

Korea Genetics Research Center, 745

Jikji-daero, Heungdeok-gu, Cheongju

28470, Korea

Tel: $+82-43-263-8280$

Fax: $+82-43-215-8288$

E-mail:kimgenee@cnuh.co.kr

Copyright@ 2019 by The Korean Society of Perinatology

This is an Open Access article distributed under the terms of the Creative Commons Attribution Non-Commercial License (http://creativecommons.org/ license/by-nc/4.0/), which permits unrestricted non-commercial use, distribution, and reproduction in any medium, provided that the original work is properly cited.
Objective: To investigate polydactyly in neonates who were admitted to neonatal intensive care unit (NICU) due to urgent medical needs.

Methods: Retrospective chart review of polydactyly neonates admitted to NICU of Chungnam National University Hospital between September 1997 and September 2018 was carried out. Patient data, type of polydactyly accompanying anomalies, genetic testing and clinical follow-up after discharge were reviewed and analyzed.

Results: Thirty-one neonates with polydactyly were admitted to NICU during the selected period. $61.3 \%$ were male. Most were admitted for the evaluation and treatment for other congenital anomalies. Ten neonates (32\%) were small for gestational age. The most frequently observed forms of polydactyly were preaxial hand polydactyly and postaxial foot polydactyly. Cardiac anomalies (35\%) were more frequent in the population than genitourinary tract anomalies (22\%), central nervous system anomalies (22\%), gastrointestinal tract anomalies (19\%) and congenital hypothyroidism. Four neonates showed abnormal genetic finding. Three neonates were diagnosed syndromic disorder after discharge (CATCH22 syndrome, VACTERL association, Joubert syndrome). Pregnancy of these neonates was complicated by maternal diabetes (13\%), hepatitis B virus (6\%), exposure to herbal medicine or smoking (6\%), pre-eclampsia and hypertension. Only one case in the study had positive family history for polydactyly.

Conclusion: Polydactyly could serve as a clue to syndromes and genetic disorders if associated with multiple major organ anomalies.

Key Words: Newborn, Polydactyly, Anomaly

\section{서론}

다지증은 사지에 발생하는 가장 흔한 선천적인 기형 중의 하나이다. 발생률은 인종, 성별 등에 따라 차이를 보이며, Malik'가 보고한 논문에 의하면 1,000명 출생아당 0.3-3.6명의 발 생률을 보이고, 한국의 경우 2018년도에 Ko 등이 발표한 자료에 따르면 다지증의 발생률 은 10,000 명 출생아당 14.1 명으로 다른 보고에서와 비슷한 발생률을 보이고 있다. 또한 한 국에서 발생하는 근골격계 선천성 기형 중 두 번째로 흔한 기형으로 점차 그 발생률이 증가 하고 있다.

다지증은 비교적 흔한 사지 기형이기 때문에 여러 문헌에서 다양한 기준으로 분류하고 있 다. ${ }^{3}$ 발생하는 위치에 따라 무지에 발생하는 무지 다지증 또는 축전성(preaxial) 다지증, 제 5 수지에 발생하는 축후성(postaxial) 다지증, 제 $2,3,4$ 수지에 발생하는 중심성(central) 또 는 축성 다지증으로 분류한다. ${ }^{4}$ 수부에서는 축전성 다지증, 족부에서는 축후성 다지증의 출 현 빈도가 높다. 백인에서는 축전성 수부 다지증, 흑인에서는 축후성 수부 다지증이 흔하다. ${ }^{5}$ 유전자나 염색체 이상에 따라 분류하기도 하고, ${ }^{6-8}$ 드물지만 임상증상에 따라 분류하기도 하 는 데 단독으로 발생하는 경우에는 'isolated'로, 다른 사지 기형이나 비-사지 기형이 동반되 는 경우에는 'associated (combined/syndromic/multiple congenital anomaly)'로 분류하기 도 한다. ${ }^{9}$

사지의 형성은 수정 후 4 주에 배아의 측벽에서 싹(bud)이 형성되어 사지의 배아 형성이 시 
작되고 수정 후 8주에 형성이 종료되어 사지의 구조를 갖추게 된다. 이 시기에 사지의 주요 선천성 기형들이 발생하게 된다. ${ }^{5}$ 분자학적인 측면에서 사지의 발달과 3 공간 축(spatial axes) 확 립에는 다양한 신호 전달 체계 및 인자들이 관여하고 있고, 이러 한 전달 체계 및 인자들의 이상은 사지 형성뿐만 아니라 전신에 영향을 끼칠 수 있다. ${ }^{10}$

다지증 발생의 위험인자로 당뇨병과 같은 산모의 질병 ${ }^{11}$ 이나 산모의 어린 나이, 음주력, 흡연력 등이 알려져 있고, ${ }^{12-15}$ 염 색체 나 유전자 이상이 연관되어 있으며,6,16 약 400 여 개의 증후군에 서 다지증이 동반되어 있다고 알려져 있다. ${ }^{17}$ 다지증은 단독으 로 발생하는 경우가 대부분이지만, 족부의 내반첨족과 같은 사 지의 기형이 동반되거나 구개열 및 구순열, 무안구증, 선천성 심 장병, 위장관계 기형, 중추신경계 장애 등 다른 기관의 기형이 동반되는 경우도 있다. 또한 파타우 증후군(Patau syndrome, Trisomy 13), 메켈 증후군(Meckel syndrome), 다운 증후군 (Down syndrome, Trisomy 21), 하이드로레살러스 증후군 (Hydrolethalus syndrome), VACTERL association, 에드워드 증후군(Edwards syndrome, Trisomy 18), 엘리스-반크레벨트 증후군(Ellis-Van Creveld syndrome) 등과 같은 증후군의 한 임상 양상으로 나타나기도 한다. ${ }^{9}$ 따라서 다지증 환자에서 미용 이나 기능적인 측면에서 수술적인 치료도 중요하지만, 다양한 전신질환의 가능성에 대하여 평가하고 선천성 심장질환과 같은 생명에 위협을 줄 수 있는 문제들을 조기에 발견하는 것 또한 중 요한 일이다. ${ }^{5}$

한국에서 다지증의 발생률이나 수술적 치료에 대한 몇몇 논 문들이 보고되었으나, ${ }^{18,19}$ 전신질환이나 증후군, 유전질환과 연 관된 다지증에 대한 분석을 시행한 연구는 없는 상황이다. 이에 저자들은 단일기관에서 신생아 중환자실에 입원하였던 다지증 환자의 진료기록을 조사하여 임상적 요인을 분석하고 장기 추 적 결과를 확인하여, 다지증이 동반된 다양한 증후군이나 염색 체 이상의 조기 진단의 단서를 확인해보고자 하였다.

\section{대상 및 방법}

1997년 9월부터 2018년 9월까지 21년의 기간 동안 충남대 학교병원 단일기관의 신생아 중환자실에 입원한 다지증 환자들 의 의무기록을 후향적으로 분석하였다. 의무기록이 미비한 경 우에는 분석 대상에서 제외하였다. 환자인자로 재태 연령, 신체 계측, 성별, 입원 당시 발견된 이상 증상, 징후 및 검사 소견, 다 지증의 분류, 가족력을 조사하였고, 퇴원 후 외래 추적관찰을 시 행한 경우 외래에서 발견된 이상 증상, 징후 및 검사 소견, 수술
적 치료에 대하여 조사하였다. 산모인자로 산전 초음파에서 다 지증 진단 유무, 산모의 연령, 출산력, 술, 담배 및 약물 노출력, 동반질환에 대하여 조사하였다. 이후 다지증의 분류나 동반 기 형에 따라 추가 분석을 시행하였다.

\section{결과}

\section{1. 임상적 특성}

총 31 명의 다지증 환자가 신생아 중환자실에 입원하였다. 이 중 남자는 19명(61.3\%), 여자는 12명(38.7\%)으로 남자가 우 세하였다. 재태 연령 37 주 미만의 미숙아로 태어난 경우는 6명 (19.4\%)이었고, 재태 연령 37주 이상의 만삭아로 태어난 경우 는 25명(80.6\%)이었다. 재태 연령 대비 10 백분위수 미만의 부 당 경량아로 태어난 경우는 10명(32\%)이었다. 연간 다지증 환 자는 2000년대 후반부터 증가하는 경향을 보였다(Fig. 1).

수부의 다지증은 23 명 $(74.2 \%)$, 족부의 다지증은 3명 $(9.7 \%)$, 수 부와 족부 다지증이 함께 있는 경우는 5명(16.1\%)이었다. 수부의 다지증 중에 축전성 다지증은 21 명 $(75 \%)$, 축후성 다지증은 7 명 (25\%)으로 축전성 다지증이 흔하였다. 족부 다지증의 경우 축성 다지합지증은 1 명(11.1\%), 축후성 다지증은 8 명 $(88.9 \%)$ 으로 축 후성 다지증이 흔하였다. 수부의 경우 우측(16명, 59.3\%)에서 흔하게 발생하였고, 족부의 경우 양측(5명, $62.5 \%)$ 에서 흔하게 발생하였다. 수부와 족부 다지증이 함께 있는 환자 5명 중 3명이 사지 모두에서 다지증이 발생하였다

외부 병원에서 출생 후 입원한 환자는 13 명(42\%)이었으며 본 병원에서 출생 후 입원한 환자는 28 명 $(58 \%)$ 이었다. 신생아 중 환자실에 입원이 필요하였던 주 요인은 심장이나 위장관 등 주 요 장기의 기형(12명, $38.7 \%)$ 이나 동반 기형 평가(4명, $12.9 \%)$ 가 절반 이상을 차지하였다(Table 1). 주요 장기에 동반 기형이

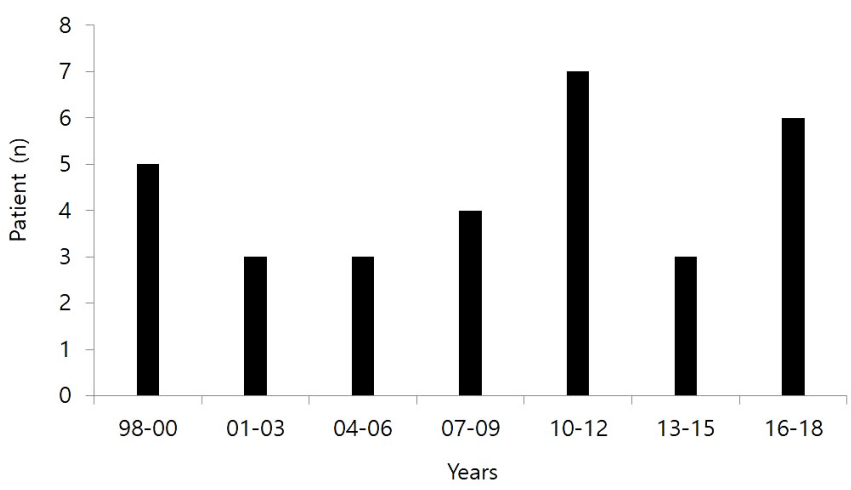

Fig. 1. Patient number of polydactyly at neonatal intensive care unit for 21 years. 
발견되었던 환자들의 특성, 염색체 검사 결과 및 임상 진단을 살 펴보았을 때 8명에서 심실 중격 결손이나 복잡한 심장질환 등 수술적 치료가 필요한 심장질환이 동반되었고, 4 명에서 심방 중 격 결손이나 동맥관 개존증으로 지속적인 추적관찰을 시행하

Table 1. Reason for Admission at NICU

\begin{tabular}{lc}
\hline Reason & Value \\
\hline Congenital heart disease & 4 \\
Gastrointestinal tract anomaly & 4 \\
For evaluation of polydactyly associated anomaly* & 4 \\
Infection & 4 \\
Prematurity & 3 \\
Respiratory problem & 3 \\
Jaundice & 3 \\
Genitourinary tract anomaly & 2 \\
CNS anomaly & 2 \\
Asphyxia & 1 \\
Hypoglycemia & 1 \\
\hline
\end{tabular}

Values are presented as number of patient.

Abbreviations: NICU, neonatal intensive care unit; CNS, central nervous system.

*Multiple polydactyly or polydactyly with odd-looking appearance.
여, 심기형(70.6\%)이 가장 많이 동반되었다. 또한 2개 이상의 주 요 장기에 기형이 있었던 환자들 11 명 중 4 명에서 염색체 이상 이 발견되었고, 염색체 검사 결과가 정상인 경우에서도 외래 추 적관찰 중에 3명이 특정 증후군으로 진단받았다(Table 2). 다지 증 분류에 따라 입원 당시 발견되었던 이상 소견, 동반 기형을 살펴보면 수부의 축전성 다지증에서 다양한 동반 기형이 발생 하였으며, 파타우 증후군의 경우 2명 모두 축후성 다지증에서 발견되었다(Table 3).

\section{2. 산모력 및 가족력}

산전 초음파에서 다지증이 진단된 경우는 2 명이었다. 산모의 나이는 25세 미만이 7명(22.6\%), 25세 이상 30세 미만 9명(29\%), 30 세 이상 35세 미만 11명(35.5\%), 35세 이상이 4명(12.9\%)이 었으며, 출산력은 초산모가 18명(58\%), 경산모가 12명(38.7\%) 이었다. 산모의 질환으로는 당뇨병 3 명, 당뇨병 및 고혈압 1 명, $\mathrm{B}$ 형간염 보균자 2 명, 전자간증 1 명이 있었으며, 당뇨병 등 다른 질 환에서는 동반 기형이 없는 경우가 있었으나 B형간염 보균자 2명 에서는 심기형, 위장관 기형 등 주요 장기 기형이 동반되었다. 임신 기간 중 음주를 한 경우는 없었으나 흡연을 한 경우는 2 명, 약물(한 약)을 복용을 한 경우는 1 명 있었으며 심기형, 위장관 기형 등 주

Table 2. Characteristics of Polydactyly Patient with Major Associated Anomalies

\begin{tabular}{|c|c|c|c|c|c|}
\hline \multirow{2}{*}{ Patient } & \multicolumn{4}{|c|}{ Associated anomalies } & \multirow{2}{*}{ Outcome } \\
\hline & $\mathrm{CHD}$ & CNS & GUT & GIT & \\
\hline 1 & ASD, Dextrocardia & Retinal dysplasia & - & Cleft palate & Trisomy 13 (expire) \\
\hline 2 & - & Hemivertebra & - & - & $46, X Y$ \\
\hline 3 & VSD, ASD & - & - & - & $46, X X$ \\
\hline 4 & VSD & Hearing loss & Renal agenesis & - & CATCH22 \\
\hline 5 & ASD & Cerebral infacrtion & - & - & $46, X X$ \\
\hline 6 & - & Lipomyelo-meningocele & Renal agenesis & - & $46, X X$ \\
\hline 7 & TOF & - & Renal agenesis, ambiguous genitalia & Cleft palate & $45, X Y, \operatorname{der}(15 ; 21)$ \\
\hline 8 & VSD, ASD & - & SUA & - & $46, X Y$ \\
\hline 9 & Common AVV & - & - & Cleft lip & Transfer \\
\hline 10 & PDA & - & Cystic renal disease & ARM & VACTERL association \\
\hline 11 & DORV & - & - & - & Transfer \\
\hline 12 & VSD & Hearing loss & Horseshoe kidney, SUA & ARM & VACTERL association \\
\hline 13 & TOF & Colpocephaly & - & - & Trisomy 13 \\
\hline 14 & PDA & - & - & Duodenal atresia & $46, X X$ \\
\hline 15 & - & - & MCDK & - & Unknown \\
\hline 16 & - & Spine lipoma & - & - & Unknown \\
\hline 17 & - & - & Hydronephrosis & - & Joubert syndrome \\
\hline
\end{tabular}

Abbreviations: CHD, congenital heart disease; CNS, central nervous system; GUT, genitourinary tract; GIT, gastrointestinal tractens; ASD, atrial septal defect; -, absent; VSD, ventricular septal defect; TOF, tetralogy of fallot; SUA, single umbilical artery; AVV atrioventricular valve; PDA, patent ductus arteriosus; ARM, anorectal malformation; DORV, double outlet right ventricle; MCDK, multicystic dysplastic kidney. 
요 장기의 기형을 동반하였다. 가족력이 있는 경우는 1 명이었다 (Table 4). 한 쌍의 일란성 쌍태아에서 수부와 족부에 동일한 형 태의 다지증이 관찰되었으나 다지증의 가족력은 없었다.

\section{3. 외래 경과}

동반 기형이 없었던 경우에는 수술적 치료 이외에는 대부분 외 래 추적관찰이 시행되지 않았다. 동반 기형이 있었던 17 명의 환자 중 사망 1 명, 심기형 수술을 위하여 전원한 2 명을 제외하고 외래 추적관찰을 시행하였으며, 외래 추적관찰 기간 중에 특정 증후군 이 진단된 경우는 4 명으로 $\mathrm{CATCH} 22$ 증후군 1명, VACTERAL association 2 명, 주버트 증후군 1 명이 있었다(Table 2). 다지증 치료의 경우 신생아 중환자실 입원 기간 동안 단순 절제나 결찰 을 시행한 경우는 8 명 $(26 \%)$ 이었으며, 다지증의 수술적 치료를 위하여 외래 추적관찰을 시행하였던 15명(48\%)의 환자 중 8명 이 생후 12 개월에서 24 개월 사이에 입원하여 전신마취 하에 수 술적 치료를 시행하였다.

\section{고찰}

한국에서 다지증은 10 대 주요 선천성 기형에 포함되는 흔한 근골격계 기형으로, 출생아 1 만 명당 다지증의 유병률은 2005 년 9.91명, 2006년 11.76명이었으며 ${ }^{20} 2008-2014$ 년의 기간에는 14 명으로 점차 유병률이 증가하고 있다. ${ }^{2}$ 본 연구에서도 표본수 가 적은 한계점은 있지만 유병률이 증가하는 경향을 보였다. 남 녀 성비를 확인해보면 본 연구에서는 남자가 $61.3 \%$ 였는데, 기 존의 보고(2005년 60.5\%, 2006년 59.7\%, 2008-2014년 57\%) 에서와 유사한 결과를 보였다. ${ }^{2,20}$ 2005-2006년 재태 연령별 다 지증의 유병률은 37 주 이상보다 37 주 미만에서 높았으며 출생 체중별 유병률은 2,500 g 이상보다 2,500 g 미만에서 높았으
나, ${ }^{20}$ 본 연구에서는 재태 연령별, 출생 체중별 총 출생아 수를 파악하기 어려워 직접적인 유병률의 차이를 비교할 수는 없었 다.

자궁내 성장 지연은 주산기 이환율 및 사망률과 밀접한 연관 이 있다. 자궁내 성장 지연의 원인인자 중에 태아인자로는 다양 한 유전질환, 선천 기형, 태아 감염, 다태 임신 등이 알려져 있 다. ${ }^{21}$ 본 연구에서도 다지증 환자의 $1 / 3$ 이 부당 경량아로 출생한

\section{Table 4. Associated Anomalies according to Maternal Factor}

\begin{tabular}{|c|c|c|c|}
\hline Patient & Maternal factor & Type of polydactyly & Associated anomaly \\
\hline 3 & HBV carrier & $\begin{array}{l}\text { Postaxial both hand, } \\
\text { foot }\end{array}$ & VSD, ASD \\
\hline 9 & Smoking & Preaxial left hand & Cleft lip, ASD, common AW \\
\hline 10 & $\begin{array}{l}\text { Herbal } \\
\text { medication }\end{array}$ & Preaxial right hand & ARM, cystic renal disease, PDA \\
\hline 12 & $\mathrm{DM}$ & Preaxial right hand & $\begin{array}{l}\text { Horseshoe kidney, ARM, single } \\
\text { umbilical artery, VSD, hearing } \\
\text { loss, congenital hypothyroi- } \\
\text { dism }\end{array}$ \\
\hline 14 & HBV carrier & Preaxial left hand & Duodenal atresia, PDA \\
\hline 15 & DM, smoking & $\begin{array}{l}\text { Preaxial left hand, } \\
\text { postaxial right } \\
\text { hand }\end{array}$ & MCDK \\
\hline 17 & DM & Postaxial both foot & Hydronephrosis \\
\hline 18 & $\begin{array}{l}\text { Severe } \\
\text { preeclampsia }\end{array}$ & Preaxial right hand & None \\
\hline 19 & $\begin{array}{l}\text { Maternal } \\
\text { polydactyly }\end{array}$ & $\begin{array}{l}\text { Postaxial both hand, } \\
\text { foot }\end{array}$ & None \\
\hline 20 & DM & Preaxial right hand & None \\
\hline 21 & $\mathrm{DM}, \mathrm{HTN}$ & Preaxial right hand & None \\
\hline
\end{tabular}

Abbreviations: HBV, hepatits B virus; VSD, ventricular septal defect; ASD, atrial septal defect; AVV atrioventricular valve; ARM, anorectal malformation; PDA, patent ductus arteriosus; DM, diabetic mellitus; MCDK, multicystic dysplastic kidney; HTN, hypertension.

Table 3. Associated Anomalies according to Polydactyly Classification

\begin{tabular}{llc}
\hline Type of polydactyly & Associated anomaly (number) & Genetic study \\
\hline Hand, preaxial & VSD (3), ASD (3), TOF, Common AVV, DORV, PDA, Renal agenesis (2), MCDK, Horseshoe kidney, Ambigus & $45, X Y$, der(15;21) Robertsonian \\
& genitalia, Duodenal atresia, ARM (2), Cleft palate, Cleft lip, Natal teeth and retention cyst, Hemivertebra (2), & translocation, 46 XX (MYH7 \\
& Spine lipoma, Cerebral infarction, Hearing loss, Single umbilical artery (2), Congenital hypothyroidism & c.2378G $>$ A (p.Arg793GIn) \\
Hand, postaxial & TOF, Colpocephaly with Callosal dysgenesis & Trisomy 13 \\
Foot, postaxial & VSD, ASD (2), Dextrocardia, Retinal dysplasia, hydronephrosis, Cleft palate & Trisomy 13 \\
Foot, central & Renal agenesis, Lipomyelomeningocele & \\
\hline
\end{tabular}

Abbreviations: VSD, ventricular septal defect; ASD, atrial septal defect; TOF, tetralogy of fallot; AVV atrioventricular valve; DORV, double outlet right ventricle; PDA, patent ductus arteriosus; MCDK, multicystic dysplastic kidney; ARM, anorectal malformation. 
것을 확인하였고, 염색체 이상 및 증후군 환자들은 모두 자궁내 발육부전 및 출생 후 부당 경량아로 확인되었으며, 1 명의 부당 경량아 환자를 제외한 9 명의 환자에서 1 개 이상의 주요 장기에 기형이 동반되어, 자궁내 성장에 영향을 줄 수 있는 인자들이 다 양한 기형 발생에도 영향을 줄 수 있음을 확인하였다. 체중 이외 의 신체 계측에서 다지증 환자의 경우 신장이 작다는 연구 결과 가 있었으나 ${ }^{22}$ 본 연구에서는 일부 다지증 환자의 신장 신체 계 측 누락으로 비교하지 못하였다.

다지증의 발생은 하지보다는 상지에서 발생 빈도가 높고, 수 부의 다지증은 축전성, 족부의 다지증은 축후성의 발생 빈도가 높다. 좌우 측의 발생 빈도에 대한 연구의 경우 수부의 경우 우 측에서 발생 빈도가 높다고 보고되었다. ${ }^{23-25}$ 기존의 한국에서 발표된 논문들에서도 수부의 다지증은 축전성 다지증의 빈도 가 높았으며, 18,20 족부의 다지증은 축전성 이외의 다지증의 빈 도가 높다고 보고되었는데 ${ }^{20}$ 본 연구에서도 수부의 축전성 다 지증의 빈도가 높고 $(75 \%)$, 족부의 축후성 다지증 빈도가 높음 (88.9\%)을 확인할 수 있었다. 한국에서 좌우 측의 발생 빈도에 대한 연구는 없었으나 본 연구에서는 수부의 경우 우측에서 발 생 빈도가 높았고(59.3\%), 족부의 경우 양측에서 발생 빈도가 높음(62.5\%)을 확인하였다.

다지증 단독으로 발생하는 경우를 제외하고, 다지증 환자에 서 동반된 기형에 대한 기존의 연구들에서는 대부분은 같은 사 지의 기형이 동반되거나 심혈관계, 중추신경계, 비뇨생식기계 의 기형이 동반되는 것으로 알려져 있다. ${ }^{9,11,16}$ 산전 초음파에서 다지증이 발견된 환자들에서 산전 동반 이상 및 염색체 검사 소 견에 따라 분석한 연구를 살펴보면 염색체 이상이 없었던 경우 경미한 기형의 경우 단일제대동맥이나 수신증과 같은 비뇨기 계 기형이나 이분척추갈림증과 같은 중추신경계 기형이 확인 되었고, 복잡한 기형으로는 다른 사지의 기형, 심실중격결손, 신 장 무형성증, 구순열 및 구개열 등이 확인되었고 임신 종결을 제 외한 환자 중에 일부에서 출생 후 Smith-Lemli-Opitz 증후군이 나 VACTERL association으로 진단받았다. 염색체 이상이 있 었던 경우에는 대부분은 파타우 증후군으로 복잡한 심기형, 심 각한 중추신경계 이상, 단일제대동맥이나 수신증과 같은 비뇨 기계 기형이나 구개열 및 구순열 등이 확인되어 절반 이상에서 임신 종결을 시행하였다. ${ }^{16}$ 본 연구에서는 기존의 연구에서와는 다르게 상당수의 환자에서 심기형이 동반된 것을 확인할 수 있 었고, 기존의 연구에서 볼 수 없었던 마제신, 낭성신질환, 모호 생식기나 중복자궁과 같은 비뇨생식기계 기형, 십이지장 폐쇄, 항 문 폐쇄 등의 위장관계 기형, 청력 장애, 선천성 갑상샘 기능저하 증 등을 확인할 수 있었다. 또한 축전성 다지증에서 다양한 기형 의 동반을 확인할 수 있었다. 파타우 증후군의 경우 모두 축후성
다지증이 발생하였는데 이는 기존의 연구에서와 동일한 결과 를 보였다. ${ }^{16}$ 다지증 환자의 양상은 인종이나 지역에 따른 차이 가 있고, 100 여 개 이상의 유전자가 다지증 형성에 연관되어져 있다고 알려져 있어 ${ }^{7}$ 이러한 요소들이 다양한 임상 양상의 발현 에 영향을 줄 수 있을 것으로 생각되나 한국을 포함한 아시아계 에서 이러한 유전자나 동반된 기형에 대한 연구가 부족하여 향 후 다지증의 유전자에 따른 추가적인 연구가 필요할 것으로 생 각된다.

임신 제 2 삼분기는 세부적인 해부학적 구조 및 기능을 검사할 수 있는 시기로 한국에서는 대부분의 임신부들이 이 시기에 정 밀 초음파를 시행하고 있고, 염색체 이상의 산전 진단에 유용한 검사로 이용되고 있다. ${ }^{26}$ 산전 초음파를 통하여 다지증의 종류 와 동반 이상 소견을 확인하여 다지증 이외에 다른 기형이 동반 된 경우에는 태아 염색체 검사를 고려해야 한다. ${ }^{16}$ 본 연구에서 는 2 명을 제외한 대부분 환자의 산전 초음파에서 다지증을 확인 할 수 없었고, 다지증 이외에 다른 장기의 기형이 발견된 경우는 약 $40 \%$ 정도였으며, 다지증과 다른 장기의 기형이 함께 확인된 경우는 1 명 밖에 없었다. 산과 의사가 산전에 제공하는 정보는 임신 종결과 같은 부모의 결정에 큰 영향을 미칠 수 있기 때문에 신중하고 다양한 방법으로 접근이 필요하지만, 높은 수준의 환 자 치료를 위해서는 출생 후 상세한 진찰 및 평가뿐만 아니라 정 밀 초음파, 염색체 검사와 같은 산전 검사를 통하여 출생 전 태 아 상태를 예측하는 것도 매우 중요한 일이다.

다지증 발생의 위험인자로는 산모의 질병, 나이, 약물 및 음주 력, 흡연력 등이 알려져 있다. 기존 연구에서 연령 기준의 차이 가 있지만 산모의 어린 나이가 위험인자로 보고되었으며, $12,13,27$ 한국에서 산모 연령별 다지증의 유병률은 큰 차이가 없었고, ${ }^{20}$ 본 연구에서는 30-35세 그룹의 유병률이 가장 높고 35세 이상 의 그룹의 유병률이 가장 낮았는데 이는 표본수, 조사 기간의 차 이 등 다양한 요인들이 영향을 미쳤을 것으로 생각된다. 출산력 에 대해서는 연관성이 없다고 보고되고 있고, 산모의 고혈압은 다지증의 발생과 연관성이 없으나 심한 자간전증의 경우 연관 성이 있다고 보고되고 있다. ${ }^{12}$ 산모의 당뇨병의 경우 태아에서 심혈관계, 중추신경계, 비뇨기계, 구개열 등 다양한 기형이 동반 될 수 있는데, 축전성 다지증에서 척추나 사지의 골격계 이상이 동반된 경우 당뇨병성 태아증을 강하게 의심해볼 수 있다고 보 고되고 있다. ${ }^{11}$ 산모 흡연력이 다지증의 발생과 연관되어 있다 는 대규모 연구들이 발표되었으나, ${ }^{28,29}$ 최근에 발표된 체계적 고 찰에서는 경향만 보이는 것(odds ratio, 1.18 [0.99,1.41])으로 발표되었다. ${ }^{15}$ 본 연구에서는 표본수가 적어 산모의 전자간증이 나 당뇨병이 다지증 발생에 영향을 주는지 타 연구와 비교해볼 수 없었으며, B형간염 보균 산모에서 태어난 환자들에서 주요 
장기의 기형이 발견되었는데, 산모의 간염과 다지증과의 연관 성에 대하여 보고한 논문은 없으나 산모의 B형간염의 보균이 태아 기형의 발생에 영향을 미친다고 알려져 있어, ${ }^{30}$ 향후 이에 대한 추가적인 연구도 필요할 것이다.

다지증 종류에 따라 수술적 치료 시기가 달라지는데, 수부의 경우 소근육 발달이 이루어지기 전인 생후 6-9개월 사이에 수 술을 하거나 수부의 기능에 나쁜 영향을 줄 수 있는 위험성이 높 을 경우에는 조기에 수술적 치료를 시행하는 것을 권하지만, 31,32 전신마취의 위험성 등의 이유로 생후 1 세까지 기다리는 경우도 적지 않다. ${ }^{33} \mathrm{~B}$ 형 축후성 다지증의 경우 전신마취의 부담을 피하 고자 신생아실에서 단순 결찰을 하기도 하지 만, ${ }^{34,35}$ 환자 상태에 따라 재수술이 필요하기도 하고 감염, 출혈, 신경종 등 합병증의 발생이나 미용적인 측면을 고려하여 뒤늦게 수술적 치료를 시 행하기도 한다. ${ }^{18,36}$ 본 연구에서 외래 추적관찰을 시행한 환자들 중 절반 이상에서 생후 12 개월에서 24 개월 사이에 전신마취 하 에 수술적 치료를 시행하거나 계획 중이었고, 경미한 축전성이 나 축후성 다지증의 경우 신생아 중환자실에서 단순 절제나 결 찰을 시행하였는데 단순 결찰을 시행하였던 축전성 다지증 환 자 일부에서 손가락 구축 등의 합병증이 발생하여 재수술한 경 우도 있었다. 따라서 다지증의 종류에 따라 수술적 치료 방법과 시기에 대하여 충분히 고민해야 좋은 결과를 얻을 수 있을 것으 로 생각된다.

본 연구는 단일기관의 신생아 중환자실에 입원한 다지증 환 자만을 대상으로 한 제한점이 있지만 다지증과 주요 장기에 다 발성 기형이 동반될 경우 다양한 증후군이나 염색체 이상의 단 서가 될 수 있음을 확인하였다. 다지증과 연관성이 낮은 동반 기 형이 있는 경우 무분별한 검사는 환자 보호자에게 심리적, 경제 적 부담을 줄 수 있지만 다지증 환자에서 심장, 중추신경계, 위 장관, 비뇨생식기계 등의 주요 장기에 다발성 기형이 동반된 경 우 출생 초기에 염색체 이상이나 특정 증후군의 진단을 위한 검 사를 적극 고려하고, 다른 질환의 발현 확인을 위하여 지속적인 외래 추적관찰이 필요할 것으로 생각된다. 선천성 기형에 대한 많은 연구와 진단 방법의 발전에도 불구하고 한국에서 주요 선 천성 기형 중에 하나인 다지증에 대한 연구는 부족한 상황으로, 향후 다지증의 산전 조기 진단 방법, 다지증 발생의 위험 요인, 다지증과 관련된 염색체, 유전자 이상 등에 대한 대규모 연구가 필요할 것으로 생각된다.

\section{References}

1) Malik S. Polydactyly: phenotypes, genetics and classification. Clin Genet 2014:85:203-12.

2) Ko JK, Lamichhane DK, Kim HC, Leem JH. Trends in the prevalences of selected birth defects in Korea (2008-2014). Int J Environ Res Public Health 2018;15:923.

3) Umair M, Ahmad F, Bilal M, Ahmad W, Alfadhel M. Clinical genetics of polydactyly: an updated review. Front Genet 2018;9:447.

4) Swanson AB, Swanson GD, Tada K. A classification for congenital limb malformation. J Hand Surg Am 1983;8(5 Pt 2):693-702.

5) Kozin SH. Upper-extremity congenital anomalies. J Bone Joint Surg Am 2003:85:1564-76.

6) Ahmed H, Akbari H, Emami A, Akbari MR. Genetic overview of syndactyly and polydactyly. Plast Reconstr Surg Glob Open 2017;5:e1549.

7) Biesecker LG. Polydactyly: how many disorders and how many genes? 2010 update. Dev Dyn 2011;240:931-42.

8) Temtamy SA, McKusick VA. The genetics of hand malformations. Birth Defects Orig Artic Ser 1978;14:i-xviii, 1-619.

9) Castilla EE, Lugarinho R, da Graça Dutra M, Salgado LJ. Associated anomalies in individuals with polydactyly. Am J Med Genet 1998;80:459-65.

10) Al-Qattan MM, Yang Y, Kozin SH. Embryology of the upper limb. J Hand Surg Am 2009;34:1340-50.

11) Adam MP, Hudgins L, Carey JC, Hall BD, Coleman K, Gripp KW, et al. Preaxial hallucal polydactyly as a marker for diabetic embryopathy. Birth Defects Res A Clin Mol Teratol 2009;85:13-9.

12) Luo $Y L$, Cheng $Y L$, Gao XH, Tan SQ, Li JM, Wang W, et al. Maternal age, parity and isolated birth defects: a population-based case-control study in Shenzhen, China. PLoS One 2013;8:e81369.

13) Reefhuis J, Honein MA. Maternal age and non-chromosomal birth defects, Atlanta--1968-2000: teenager or thirty-something, who is at risk? Birth Defects Res A Clin Mol Teratol 2004;70:572-9.

14) Pauli RM, Feldman PF. Major limb malformations following intrauterine exposure to ethanol: two additional cases and literature review. Teratology 1986;33:273-80.

15) Hackshaw A, Rodeck C, Boniface S. Maternal smoking in pregnancy and birth defects: a systematic review based on 173687 malformed cases and 11.7 million controls. Hum Reprod Update 2011;17:589-604.

16) Filges I, Kang A, Hench J, Wenzel F, Bruder E, Miny P, et al. Fetal polydactyly: a study of 24 cases ascertained by prenatal sonography. J Ultrasound Med 2011;30:1021-9.

17) Johns Hopkins University. $\mathrm{OMIM}^{\circledR}$ - Online Mendelian Inheritance in Man ${ }^{\circledast}$ [online] 2019 [cited 2019 Apr 22]. Available from:URL: https:// www.omim.org/.

18) Kim BJ, Choi JH, Kwon ST. Surgical treatment of axial polysyndactyly and postaxial polydactyly of the hand in Korean: a clinical analysis of 24 cases. J Korean Soc Surg Hand 2017;22:20-6.

19) Kim D, Park SK, Kim DC, Oh SJ, Yoo KY. Nationwide estimation for incidence at birth of congenital polydactyly and syndactyly in Korean. J Korean Soc Plast Reconstr Surg 2003;30:24-32. 
20) Choi JS, Seo K, Han YJ, Lee SW, Boo YK, Lee SW, editors. Congenital anomaly survey and statistics. Sejong: Korea Institute for Health and Social Affairs; 2009 Dec. Report No.: 11-1351000-000517-12.

21) Suhag A, Berghella V. Intrauterine growth restriction (IUGR): etiology and diagnosis. Curr Obstet Gynecol Rep 2013;2:102-11.

22) Pérez-Molina JJ, Alfaro-Alfaro N, López-Zermeño MC, García-Calderón MA. Polydactyly in 26,670 consecutive births. The clinical characteristics, prevalence and risk factors. Bol Med Hosp Infant Mex 1993;50:803-8.

23) Xiang Y, Bian J, Wang Z, Xu Y, Fu Q. Clinical study of 459 polydactyly cases in China, 2010 to 2014. Congenit Anom (Kyoto) 2016;56:226-32.

24) Castilla E, Paz J, Mutchinick O, Muñoz E, Giorgiutti E, Gelman Z. Polydactyly: a genetic study in South America. Am J Hum Genet 1973;25:40512.

25) Malik S, Ullah S, Afzal M, Lal K, Haque S. Clinical and descriptive genetic study of polydactyly: a Pakistani experience of 313 cases. Clin Genet 2014:85:482-6.

26) Song MJ. Fetal sonography for the detection of chromosomal abnormality. J Korean Soc Ultrasound Med 2011;30:75-82.

27) Hollier LM, Leveno KJ, Kelly MA, MCIntire DD, Cunningham FG. Maternal age and malformations in singleton births. Obstet Gynecol 2000;96(5 Pt 1):701-6.
28) Man LX, Chang B. Maternal cigarette smoking during pregnancy increases the risk of having a child with a congenital digital anomaly. Plast Reconstr Surg 2006;117:301-8.

29) Honein MA, Paulozzi LJ, Watkins ML. Maternal smoking and birth defects: validity of birth certificate data for effect estimation. Public Health Rep 2001;116:327-35.

30) Tan J, Huang S, He G, Tang L, Ren Y, Zheng J, et al. Maternal hepatitis B surface antigen carrier status and its impact on neonatal outcomes: a cohort study of 21947 singleton newborns in China. J Matern Fetal Neonatal Med 2017;30:2219-24.

31) Ezaki M. Radial polydactyly. Hand Clin 1990;6:577-88.

32) Simmons BP. Polydactyly. Hand Clin 1985;1:545-65.

33) Faust KC, Kimbrough T, Oakes JE, Edmunds JO, Faust DC. Polydactyly of the hand. Am J Orthop (Belle Mead NJ) 2015;44:E127-34.

34) Katz K, Linder N. Postaxial type B polydactyly treated by excision in the neonatal nursery. J Pediatr Orthop 2011;31:448-9.

35) Samra S, Bourne D, Beckett J, Matthew M, Thomson JG. Decision-making and management of ulnar polydactyly of the newborn: outcomes and satisfaction. J Hand Surg Asian Pac Vol 2016;21:313-20.

36) Rathjen NA, Rogers TS, Garigan TP, Seehusen DA. Management of postaxial polydactyly in the neonatal unit. J Am Osteopath Assoc 2017;117: 719-21. 